\begin{tabular}{|c|l|}
\hline Title & Urban shade as a cry ptic habitat : fern distribution in building gaps in Sapporo, northern Japan \\
\hline Author(s) & Kajihara, Kazumitsu; Y amaura, Y uichi; Soga, Masashi; Furukawa, Y asuto; Morimoto, Junko; Nakamura, Futoshi \\
\hline Citation & $\begin{array}{l}\text { Urban ecosystems, 19(1), 523-534 } \\
\text { https://doi.org/10.1007/311252-015-0499-8 }\end{array}$ \\
\hline Issue Date & 2016-03 \\
\hline Doc URL & http://hdl.handle.net/2115/64616 \\
\hline Rights & The final publication is available at link.springer.com \\
\hline Type & article (author version) \\
\hline File Information & UE19-1_523-534.pdf \\
\hline
\end{tabular}

Instructions for use 


\section{Urban shade as a cryptic habitat: Fern distribution in building gaps in}

\section{Sapporo, northern Japan}

3 *Kazumitsu Kajihara ${ }^{1}$, Yuichi Yamaura ${ }^{1,2}$, Masashi Soga ${ }^{1}$, Yasuto Furukawa ${ }^{1}$, Junko

4 Morimoto $^{1}$, and Futoshi Nakamura ${ }^{1}$

$5 \quad{ }^{1}$ Graduate School of Agriculture, Hokkaido University, 9 Kita, 9 Nishi, Kita-ku, Sapporo

6 060-8589, Japan

$7 \quad{ }^{2}$ Department of Forest Vegetation, Forestry and Forest Products Research Institute, 1

8 Matsunosato, Tsukuba, Ibaraki 305-8687, Japan

$9 \quad$ *Corresponding author

$10 \quad$ Tel.: +81 117063343.

11 E-mail addresses: gkbdk629@gmail.com (K. Kajihara). 


\section{Abstract}

14 Biodiversity conservation and restoration in cities is a global challenge for the 21st century. Unlike other common ecosystems, urban landscapes are predominantly covered by gray, artificial structures (e.g., buildings and roads), and remaining green spaces are scarce. Therefore, to conserve biodiversity in urban areas, understanding the potential conservation value of artificial structures is vital. Here, we examined factors influencing the distribution of ferns in building gaps, one of the more common artificial structures, in urban Sapporo, northern Japan. We observed 29 fern species, which corresponds to $30 \%$ of all fern species previously recorded in Sapporo. The four dominant species were Equisetum arvense, Matteuccia struthiopteris, Dryopteris crassirhizoma Nakai, and Athyrium yokoscense. Statistical analyses showed that their distribution patterns in building gaps were associated with both local- and landscape-scale environmental factors. Although ground cover type and distance from continuous forests were the most important determinants, other factors such as the amount of solar radiation, habitat age (years after building development), and urban district type also affected fern distribution. These results suggest that building gaps act as an important habitat for ferns in highly urbanized landscapes. Policy makers and city planners should therefore not overlook these cryptic habitats. Clarifying the ecological functions of artificial structures will both further our understanding of novel ecosystems and develop a new framework for conserving and restoring biodiversity in human-modified landscapes.

Keywords: Building gaps; Ground cover; Isolation effect; Novel ecosystems; Urban matrix; Urban maturation 
Urbanization is one of the main causes of global biodiversity decline in the 21st century (McKinney 2002; Grimm et al. 2008). Although urban areas around the world arguably represent the most intensive land-use type (Foley et al. 2005), they have potentially high ecological value for regional biological communities (Imhoff et al. 2004; Yamaura et al. 2011). Indeed, the distributions of rare and endemic plants and animals are often spatially overlapped with urbanized areas (e.g., Kowarik 2011). Urban biodiversity is also essential for the maintenance and improvement of human well-being and health (Fuller et al. 2007; Irvine et al. 2013). Even in urban areas, contact with nature has a crucial role in engaging and reconnecting people with the natural world (i.e., preventing the "extinction of experience”; Miller and Hobbs 2002; Miller 2005). Consequently, increasing attention has been given to the conservation and restoration of biodiversity in urban areas (Dearborn and Kark 2009).

Nonetheless, conserving and restoring biological diversity in urban areas is challenging (Blair1996; McKinney 2002; Stagoll 2010), largely because green spaces, vital habitats for urban wildlife (Ikin 2013; Soga et al. 2014), are typically scarce in urbanized areas (Fuller and Gaston 2009). Rather, large portions of the landscape are dominated by artificial structures (e.g., roads, houses and high-rises; so-called "gray infrastructure”) that do not exist in natural ecosystems. This drastic land-use modification greatly alters both abiotic and biotic conditions (Gaston 2010), and makes urban landscapes a “novel ecosystem” (Hobbs et al. 2006; Faeth et al. 2011). Therefore, to successfully conserve biodiversity in urban areas, focusing on the conservation value of remaining green spaces is insufficient. However, as such a green space-based 
approach has long been the standard in urban ecological studies (Alvey 2006), the potential ecological roles of artificial structures are mostly unknown.

Building gaps are common in urban environments (Moonen et al. 2012), and in Japan, their size and other attributes are often legally determined by various safety and aesthetic considerations (e.g., fire safety and shading of nearby buildings; The Building Standard Law of Japan 2013). In the city of Sapporo, the total area of building gaps (1,368 ha, calculated by multiplying the perimeter distance of all buildings by an average gap width of 0.6 m; The Geographical Survey Institute 2011; see Fig. 1) amounts to $60 \%$ of that of all public green spaces in the city. Given the spatial extent of building gaps in the urban matrix (Fig. 1), understanding their potential conservation value represents a potentially important opportunity to conserve urban biodiversity (Goddard et al. 2010). In particular, as building gaps are generally not managed after development, they are likely to act as “cryptic habitats” hidden in urban environments.

Ferns are a suitable taxon with which to investigate the ecological roles of building gaps for several reasons. First, ferns occupy even tiny microhabitats within urban areas (e.g., stone- and roadside walls: Murakami et al. 2007; Murakami and Morimoto 2008). Second, because the environmental conditions of building gaps are often similar to those of natural fern habitats (i.e., shady environments), building gaps are likely habitats for several fern species. Third, since ferns disperse efficiently via small, lightweight spores (Barrington 1993), they can colonize many potentially suitable habitats despite landscape-scale factors affecting their distributions (Faria et al. 2007). 
Sapporo, northern Japan. Results showed the general prevalence of ferns in building gaps and that fern distribution was influenced by a combination of local- and landscapescale environmental factors. Based on these results, we suggest that clarifying the ecological roles of cryptic habitats hidden in urban areas would enhance our understanding of urban ecosystems and further the development of novel conservation methods.

\section{Methods}

\section{$\underline{\text { Study area and site selection }}$}

All fieldwork was conducted in Sapporo, Hokkaido, northern Japan. Sapporo is densely populous, with nearly 2,000,000 people in an area of only 1,121 km² (Sapporo City Statistical Report 2012). Sapporo is located in southwest Hokkaido on the Ishikari Plain. Annual mean air temperature and total annual precipitation in the region are $8.5^{\circ} \mathrm{C}$ and 1,007 mm, respectively. A continuous forest in southwestern Sapporo accounts for $63 \%\left(706 \mathrm{~km}^{2}\right.$ ) of the overall green space in the city (Greenery Promotion Department, Environmental Bureau, Sapporo 2011). Ninety fern species were found in Sapporo city including our study area and surrounding forest areas (Hara 1992). Almost all these species are forest species, and the surrounding forests can be source habitats for the habitats in the urban area.

In our study area, all residential areas were categorized into land-use districts (hereafter called district types) according to the ratio of the building footprint area to the total floor area (The Building Standard Law of Japan 2013). In Japan, district types are 
normally classified into 12 types: 7 residential, 3 industrial, and 2 commercial. In this study, we randomly selected 85 study sites, each of approximately $200 \mathrm{~m}^{2}$, covering as wide a range of district types as possible, and with each study site comprising one district type only (Fig. 2; Table 1).

\section{$\underline{\text { Field surveys }}$}

Field surveys were conducted from June to August 2013. We established survey plots at all accessible building gaps, excluding those that were artificially managed. To determine whether building gaps were artificially managed, we also conducted interviews for residents. We recorded all fern species in each survey plot (i.e., building gaps) based on Asano and Kuwabara (1990) and Iwatsuki (1992) and Kurata and Nakaike (1997), excluding artificially landscaped areas. When it was difficult to identify the plant species occurring the plots, we collected specimen, and identified them in the laboratory. We also recorded two local-scale environmental factors: ground cover type and habitat age (years after building development). Ground cover was classified into one of three categories: gravel (class 1, particle size $>11 \mathrm{~mm}$ ), soil (class 2, $<10 \mathrm{~mm}$ ), and bryophytes (class 3). These categories are rough proxies for ground humidity, whereby gravel is likely to be least humid, soil is intermediate, and bryophytes are most humid. Habitat age was also classified into four categories: less than 10 years (class 1); 11-20 years (class 2); 21-30 years (class 3); and >31 years (class 4). We established survey plots so that each plot contained uniform ground cover types and habitat ages. Plot area and the number of survey plots per study site ranged from 1.0 to $27.0 \mathrm{~m}^{2}$ (mean $4.7 \pm 2.7 \mathrm{SD}$ ), and from 5 to 37 plots (mean $27.9 \pm 6.3 \mathrm{SD}$, total 2,373), 
respectively.

\section{$\underline{\text { GIS analyses }}$}

We calculated the amount of solar radiation and the distance from continuous forest for each study site using Geographical Information System software [ArcGIS 10.0; Environmental Systems Research Institute (ESRI), Redlands, CA 2011]. To calculate the amount of solar radiation, we used laser profiler data provided by the Hokkaido Development Bureau (hereafter called LP data). LP data are topographical data measured by aerial laser surveys. Aerial laser surveys obtain three-dimensional spatial data by analyzing pulses emitted from an airborne laser as they reflect off the

136 ground and return. The accuracy (standard deviation) of the original data is $<25 \mathrm{~cm}$

137 horizontally. We used the original LP data without removing structures (e.g., houses, 138 office buildings). We assumed the surface of each structure was flat, and used the building height as the maximum value of lazar point. Then, we created $0.5-\mathrm{m}$ resolution

140 digital surface models (DSMs) of our survey areas. To calculate the amount of solar

141 radiation (the sum of direct solar radiation and sky solar radiation) during the field survey, we used ArcGIS Spatial Analyst tools and our DSMs, assuming the solar

143 radiation levels on July 1, 2013 (from 4.1 to 5829.6, mean 2459.4 \pm 1160.6 SD). We

144 defined the solar radiation of each plot as the maximum radiation value for that plot. For

145 each survey plot, we also measured the straight-line distance from the nearest

146 continuous forest (Fig. 2). 
We examined the occurrence probabilities of four fern species found in $>5 \%$ (120

150 plots) of all survey plots: Equisetum arvense L. (Fig.3a), Matteuccia struthiopteris (L.)

151 Tod. (Fig.3b), Dryopteris crassirhizoma Nakai (Fig.3c), and Athyrium yokoscense

152 (Franch. et Sav.) H. Christ (Fig.3d: see also Appendix 1). These four fern species differ markedly in their habitat preferences (E. arvense: roadsides, $M$. struthiopteris: grasslands, D. crassirhizoma: forest floors, A yokoscense: forest edges; Asano and Kuwabara 1990; Iwatsuki 1992; Kurata and Nakaike 1997). Additionally, we grouped another 25 observed species into a single group (hereafter called OTHERS25, and for convenience, referred to as a fifth “collective” fern species) and examined its collective occurrence probability in later analyses. All 25 species in this group have similar woodland habitat preferences (Asano and Kuwabara 1990; Iwatsuki 1992; Kurata and Nakaike 1997).

All analyses were performed in R version 3.0.2 (R Core Team 2013). To investigate the effect of each environmental variable on the occurrence probabilities of the five fern species (four major species and OTHERS25), we used generalized linear mixed models (GLMMs) with the 'glmer' function in the lme4 package (Bates and Sarkar 2007). Ground cover types (classes 1-3), habitat age (classes 1-4), district types 166 (classes 1-5; see Table 2), the amount of solar radiation, and the distance from continuous forest were used as continuous explanatory variables. To control for the effects of site-specific factors, we used site ID (85 sites) as a random effect. 
constant, the plot-level occurrence probability changes with plot area. Therefore, we assumed that the number of individuals followed a Poisson distribution and used the probability that at least one individual occurs at each survey plot (“occurrence probability” hereafter) as a response variable. We used a complementary log-log link function (c-loglog; McCullagh and Nelder 1989), with survey plot area as an offset term to account for differences in area among survey plots:

$\operatorname{Prob}\left(N_{i} \geq 1\right)=1-\exp \left[-\exp \left(\beta_{0}+\boldsymbol{\beta} \mathbf{x}_{\mathbf{i}}+\log \left(A_{i}\right)\right)\right]$ (Equation 1) where $N_{i}$ is the number of individuals in plot $i$ and $\operatorname{Prob}\left(N_{i} \geq 1\right)$ is the probability that at least one individual occurs in plot $i$ (i.e., the occurrence probability). $\beta_{0}$ is the model intercept, while $\mathbf{x}_{\mathbf{i}}$ and $\boldsymbol{\beta}$ are covariates of plot $i$ and their coefficients, respectively. $A_{i}$ is the area of plot $i$ and $\log \left(A_{i}\right)$ is an offset term, whose coefficient we fixed as 1 . The random effect is not shown in this equation.

The five explanatory variables were not highly correlated with each other $(|r|<$ 0.31; Appendix 2). We built full models, including all five explanatory variables (ground cover type, habitat age, district type, the amount of solar radiation, and distance from continuous forests) for each species. Using the coefficients derived from the full models, we plotted the occurrence probabilities as predicted by each of the five explanatory variables. Although ground cover type, habitat age, and district type were not strictly continuous values, we included their predicted curves for convenience.

\section{Results}

In 2,373 study plots (building gaps), we observed 29 fern species (mean $0.87 \pm$ 
0.80 SD, range: 0-8). All of them were native species in Japan, and no endangered species were included. Although there were two open-land species (E. arvense and $M$. struthiopteris), main habitats of the other species were forests. The four most commonly observed species were $E$. arvense (observed in 54\% of our study plots), $M$. struthiopteris (8\%), D. crassirhizoma (6\%), and A. yokoscense (6\%) (Appendix 1).

\section{Landscape-scale environmental factors}

For D. crassirhizoma, the highest occurrence probabilities were predicted in category 5 districts, whereas those of $E$. arvense were predicted in category 1 districts (Fig.4; Tables 1, 2). The probability of E. arvense occurrence increased significantly with increasing distance from continuous forest, whereas those of the other four fern species significantly decreased (Fig.4; Table 2).

\section{$\underline{\text { Local-scale environmental factors }}$}

Ground cover types significantly affected the occurrence probabilities of all five fern species. Equisetum arvense occurrence probabilities were highest in gravel-covered plots, whereas those of the four other species were highest in plots with bryophyte cover (Fig.4; Table 2). Furthermore, E. arvense and A. yokoscense occurrence probabilities increased significantly with increasing habitat age (Fig.4; Table 2). Athyrium yokoscense, D. crassirhizoma, and OTHERS25 occurrence probabilities were all negatively related to the amount of solar radiation (Fig.4; Table 2). 
To our knowledge, this is the first study to demonstrate the ecological importance

217 of building gaps, which represent large portions of the urban landscape (Fig. 1). Overall, our results show that the distribution of ferns in urban building gaps was influenced by both local- and landscape-scale environmental factors. We observed 29 fern species in our field surveys, which represent $30 \%$ of all fern species previously recorded in Sapporo City (90 species; Hara 1992). Furthermore, the most common species, E. arvense, was found in more than half of the building gaps. These results suggest that building gaps potentially function as wildlife habitats even in highly urbanized landscapes, showing important implications for the conservation and restoration of biodiversity where most natural areas have already been lost (Fuller and Gaston 2009). Artificial structures such as building gaps have been dismissed as gray infrastructure (inhospitable habitat matrices surrounding focal green spaces), and their conservation values largely overlooked (Bengston et al. 2004). This is partly because, as the majority of building gaps fall on private property, normal statutory management options do not apply (Norton 2000). However, since creating and maintaining new green spaces in urban areas is costly (Naidoo et al. 2006), conservation programs focusing on artificial structures may represent a cost-effective and worthwhile alternative (cf. "urban reconciliation ecology”; Rosenzweig 2001; Francis and Lorimer 2011).

In this study, the occurrence probabilities of $M$. struthiopteris, D. crassirhizoma, A. yokoscense, and OTHERS25 were negatively related to their distance from continuous forest, suggesting that continuous forests surrounding urban areas act as source habitats for ferns, which is consistent with studies on other taxa (e.g., butterflies: 
Soga and Koike 2013; amphibians: Fuyuki et al. 2014; birds: Natuhara and Imai 1999).

On the other hand, the probability of $E$. arvense occurrence was positively related to its distance from continuous forest. This contrasting distribution of E. arvense can be explained by the species' ecology. Unlike other ferns, E. arvense is adapted to sunny and dry habitats such as agricultural or cleared lands, and roadsides (Williams 1979; Andersson and Lundegårdh 1999). In our study areas, these open lands are usually found some distance from continuous forests (K. Kajihara, unpublished data), likely explaining our result.

Fern distribution was also affected by district type. For D. crassirhizoma, the highest occurrence probabilities occurred in the most urbanized district type (category 5 districts). This was unexpected, since D. crassirhizoma is a woodland species usually

249 found on the forest floor (Asano and Kuwabara 1990; Iwatsuki 1992, Kurata and 250 Nakaike 1997). One potential explanation is that tall buildings acted like the forest canopy, creating a shaded microenvironment similar to the forest floor (cf. Decandido and Allen 2006).

In addition to landscape-scale environmental factors, local-scale factors (ground cover type, the amount of solar radiation, and habitat age) also affected fern distributions. The occurrence probabilities of D. crassirhizoma, M. struthiopteris, A. yokoscense, and OTHERS25 were higher in relatively shady plots and plots with significant bryophyte cover (i.e., more moisture; Fig.4). Bryophyte cover may help to retain ground moisture (Pharo et al. 1999), and consequently to facilitate fern growth. Solar radiation is detrimental to fern persistence because it causes habitat desiccation (Richard et al. 2000). Therefore, it is not surprising that both ground cover type and the 
amount of solar radiation have strong effects on fern distribution (Fig.4).

Habitat age also influenced fern distribution patterns. The occurrence probabilities of both $E$. arvense and A. yokoscense were positively related to habitat age (Fig.4), suggesting that the colonization and establishment of ferns in building gaps may take considerable time, as seen in the range expansion of other exotic species (Sakai et al. 2001). This result raises the possibility that populations of some species can recover as urban ecosystems mature (cf. Yamaura et al. 2012). This is an important point, as urban biological communities are usually thought to degrade as cities age (Hahs et al. 2009; Soga et al. 2013). Urban biological communities likely have longer-term, more complex dynamics than previously thought (Ramalho and Hobbs 2012).

At present, cities around the world are expanding and becoming denser (Seto et al. 2012). Indeed, the number of mega cities (cities with more than 10 million people) has increased more than tenfold in the past 50 years (United Nations 2011), which suggests that the world's ecosystems are changing toward more human-built, modified, and engineered systems. We show that even in highly modified landscapes, artificial structures can harbor and even create suitable habitat, and that both local- and landscape-level factors affect their function. Therefore, to conserve and restore urban biodiversity, city planners and policy makers should not overlook the conservation potential of these cryptic habitats that are "hidden in plain sight.” Although we studied only ferns in building gaps, other types of artificial structures (e.g., drainage channels and stone masonry) likely act as cryptic habitats for other taxa. Clarifying the potential ecological functions of artificial structures in urban areas will lead not only to a better understanding of novel urban ecosystems (Hobbs et al. 2006), but to a novel framework 
for conserving and restoring urban biodiversity.

\section{Acknowledgment}

We are extremely grateful to the householders and landowners in Sapporo city who made their building gaps available. Thanks to M. Saitoh and Y. Shida for fern identification and K. Murakami for his helpful comments and discussion. We also thank

J.T. Lundholm and an anonymous referee for their helpful comments on an earlier version of this manuscript. YY was supported by JSPS KAKENHI Grant no. 23248021 and MS partly by JSPS KAKENHI Grant no. 243222.

\section{References}

Alvey AA (2006) Promoting and preserving biodiversity in the urban forest. Urban Forest Urban Green 5: 195-201.

Andersson TN, Lundegårdh B (1999) Growth of field horsetail (Equisetum arvense) under low light and low nitrogen conditions. Weed Sci 47:41-46.

Antrop M (2004) Landscape change and the urbanization process in Europe. Landsc Urban Plan 67:

$$
\text { 9-26. }
$$

Asano S, and Kuwabara Y (eds) (1990) The ecological encyclopedia of wild plants in Japan. Pteridophytes, Gymnosperms, and Angiosperms (Coripetalae). Zenkoku Noson Kyoiku Kyokai, Japan. [in Japanese]

Barrington DS (1993) Ecological and historical factors in fern biogeography. J Biogeogr 20: 275-279.

Baum KA, Haynes KJ, Dillemuth FP, Cronin JT (2004) The matrix enhances the effectiveness of corridors and stepping stones. Ecology 85: 2671-2676.

Bengston DN, Fletcher JO, Nelson KC (2004) Public policies for managing urban growth and protecting open space: policy instruments and lessons learned in the United States. Landsc Urban Plan 69: 271-286. 
domestic garden-Its contribution to urban green infrastructure. Urban Forest Urban Green 11: 129-137.

Dearborn DC, Kark S (2010) Motivations for conserving urban biodiversity. Conserv Biol 24: 432440.

DeCandido R, Allen D (2006) Nocturnal hunting by peregrine falcons at the empire state building, New York City. Wilson J Ornithol 118: 53-58.

Faeth SH, Bang C, Saari S (2011) Urban biodiversity: patterns and mechanisms. Ann NY Acad Sci 1223: 69-81.

Faria D, Paciencia MLB, Dixo M, Laps RR, Baumgarten J (2007) Ferns, frogs, lizards, birds and bats in forest fragments and shade cacao plantations in two contrasting landscapes in the Atlantic forest, Brazil. Biodivers Conserv 16: 2335-2357.

Foley JA, DeFries R, Asner GP, Barford C, Bonan G, Carpenter SR, Chapin FS, Coe MT, Daily GC, Gibbs HK, Helkowski JH, Holloway T, Howard EA, Kucharik CJ, Monfreda C, Patz JA, Prentice IC, Ramankutty N, Snyder PK (2005) Global consequences of land use. Science 309: 570-574.

Francis RA, Lorimer J (2011) Urban reconciliation ecology: the potential of living roofs and walls. J Environ Manage 92: 1429-1437.

Fuller RA, Irvine KN, Devine-Wright P, Warren PH, Gaston KJ (2007) Psychological benefits of greenspace increase with biodiversity. Biol Lett 3: 390-394.

Fuller RA, Gaston KJ (2009) The scaling of green space coverage in European cities. Biol Lett 5: 352-355.

Fuyuki A, Yamaura Y, Nakajima Y, Ishiyama N, Akasaka T, Nakamura F (2014) Pond area and distance from continuous forests affect amphibian egg distributions in urban green spaces: A case study in Sapporo, Japan. Urban Forest Urban Green 13: 397-402.

Gaston KJ (eds) (2010) Urban ecology. Cambridge University Press.

Geographical Survey Institute (2011) Basic map information. Bigger than 1/2,500 scale maps. the outer peripheral lines constituting all buildings. [in Japanese].

Greenery Promotion Department, Environmental Bureau, Sapporo (2011) Basic Plan of Green in Sapporo. Greenery Promotion Department, Environmental Bureau, Sapporo, City of Sapporo, Hokkaido, Japan.

Goddard MA, Dougill AJ, Benton TG (2010) Scaling up from gardens: biodiversity conservation in urban environments. Trends Ecol Evol 25: 90-98.

Grimm NB, Faeth SH, Golubiewski NE, Redman CL, Wu J, Bai X, Briggs JM (2008) Global change and the ecology of cities. Science 319: 756-760.

Hahs AK, McDonnell MJ, McCarthy MA, Vesk PA, Corlett RT, Norton BA, Clemants SE, Duncan, RP, Thompson K, Schwartz MW, Williams NS (2009) A global synthesis of plant extinction 
rates in urban areas. Ecol Lett 12: 1165-1173.

Hara M (1992) Flora of Sapporo. Hokkaido University Press, Sapporo, Japan. [in Japanese].

Hobbs RJ, Arico S, Aronson J, Baron JS, Bridgewater P, Cramer VA, Epstein PR, Ewel JJ, Klink CA, Lugo AE, Norton D, Ojima D, Richardson DM, Samderson EW, Valladares F, Vila M, Zamora R, Zobel M (2006) Novel ecosystems: theoretical and management aspects of the new ecological world order. Glob Ecol Biogeogr 15: 1-7.

Ikin K, Beaty RM, Lindenmayer DB, Knight E, Fischer J, Manning AD (2013) Pocket parks in a compact city: how do birds respond to increasing residential density? Landsc Ecol 28: 45-56. Imhoff ML, Bounoua L, DeFries R, Lawrence WT, Stutzer D, Tucker CJ, Ricketts T (2004) The consequences of urban land transformation on net primary productivity in the United States. Remote Sensing Environ 89: 434-443.

Irvine KN, Warber SL, Devine-Wright P, Gaston KJ (2013) Understanding urban green space as a health resource: A qualitative comparison of visit motivation and derived effects among park users in Sheffield, UK. Int J Environ Res Public Health 10: 417-442.

Iwasa Y, Kubo T (1997) Optimal size of storage for recovery after unpredictable disturbances. Evolutionaly Ecology 11: 41-65.

Iwatsuki K (eds) (1999) Ferns and fern allies of Japan. Heibonsha Ltd., Publishers, Tokyo, Japan. [in Japanese].

Kira T (1949) Forest zones of Japan. Ringyo Gizyutu Kyokai, Tokyo, Japan. [in Japanese].

Kowarik I (2011) Novel urban ecosystems, biodiversity, and conservation. Environ Pollut 159: 19741983.

Kurata S, Nakaike T (1997) Illustrations of pteridophytes of Japan. Vol. 1-8. Univ. of Tokyo Press. Tokyo, Japan [in Japanese].

McCullagh P, Nelder JA (1989) Generalized linear models Second ed. CRC press, New York.

McKinney ML (2002) Urbanization, Biodiversity, and Conservation The impacts of urbanization on native species are poorly studied, but educating a highly urbanized human population about these impacts can greatly improve species conservation in all ecosystems. BioScience 52: 883890.

Miller JR, Hobbs RJ (2002) Conservation where people live and work. Conserv Biol 16: 330-337.

Miller JR (2005) Biodiversity conservation and the extinction of experience. Trends Ecol Evol 20: 430-434.

Moonen P, Defraeye T, Dorer V, Blocken B, Carmeliet J (2012) Urban Physics: effect of the microclimate on comfort, health and energy demand. Front Architect Res 1: 197-228.

Murakami K, Matsui R, Morimoto Y (2007) Northward Invasion and Range Expansion of the Invasive Fern Thelypteris dentata (Forssk.) St. John into the Urban Matrix of Three Prefectures in Kinki District, Japan. Amer Fern J 97: 186-198. 
384

385

386

387

388

389

390

391

392

393

394

395

396

397

398

399

400

401

402

403

404

405

406

407

408

409

410

411

412

413

414

415

416

417

418

419

Murakami K, Morimoto Y (2008) Range Expansion of Two Tropical to Subtropical Ferns, Ladder Brake (Pteris vittata L.) and Lace Fern (Microlepia strigosa (Thunb. ex Murray) K. Presl.), in the Urban Osaka Bay Area, Western Japan. Amer Fern J 98: 171-176.

Naidoo R, Balmford A, Ferraro PJ, Polasky S, Ricketts TH, Rouget M (2006) Integrating economic costs into conservation planning. Trends Ecol Evol 21: 681-687.

Natuhara Y, Imai C (1999) Prediction of species richness of breeding birds by landscape-level factors of urban woods in Osaka Prefecture, Japan. Biodivers Conserv 8: 239-253.

Norton DA (2000) Conservation biology and private land: shifting the focus. Conserv Biol 14: 12211223.

Pharo EJ, Beattie AJ, Binns D (1999) Vascular plant diversity as a surrogate for bryophyte and lichen diversity. Conserv Biol 13: 282-292.

Prugh LR, Hodges KE, Sinclair AR, Brashares JS (2008) Effect of habitat area and isolation on fragmented animal populations. Proc Nat Acad Sci 105: 20770-20775.

Ramalho CE, Hobbs RJ (2012) Time for a change: dynamic urban ecology. Trends Ecol Evol 27: 179-188.

R Core Team (2013) R: A language and environment for statistical computing. R Foundation for Statistical Computing, Vienna, Austria. URL http://www.R-project.org/

Richard M, Bernhardt T, Bell G (2000) Environmental heterogeneity and the spatial structure of fern species diversity in one hectare of old-growth forest. Ecography 23: 231-245.

Rosenzweig ML (2001) Loss of speciation rate will impoverish future diversity. Proc Nat Acad Sci 98: 5404-5410.

Ruiters C, McKenzie B (1994) Seasonal allocation and efficiency patterns of biomass and resources in the perennial geophyte Sparaxis grandiflora subspecies fimbriata (Iridaceae) in lowland coastal fynbos, South Africa. Ann Bot 74: 633-646.

Sakai AK, Allendorf FW, Holt JS, Lodge DM, Molofsky J, With KM, Baughman S, Cabin RJ, Cohen JE, Ellstrand NC, McCauley DE, O'Neil P, Parker IM, Thompson JN, Weller SG (2001) The population biology of invasive species. Ann Rev Ecol Syst 32: 305-332.

Seto KC, Güneralp B, Hutyra LR (2012) Global forecasts of urban expansion to 2030 and direct impacts on biodiversity and carbon pools. Proc Nat Acad Sci 109: 16083-16088.

Soga M, Koike S (2013) Patch isolation only matters for specialist butterflies but patch area affects both specialist and generalist species. J For Res 18: 270-278.

Soga M, Yamaura Y, Koike S (2013) From ecological pessimism to conservation chance: reviving living dead in changing landscapes. Anim Conserv 16: 16-18.

Soga M, Yamaura Y, Koike S, Gaston KJ (2014) Woodland remnants as an urban wildlife refuge: a cross-taxonomic assessment. Biodivers Conserv 23: 649-659.

Stagoll K, Manning AD, Knight E, Fischer J, Lindenmayer DB (2010) Using bird-habitat 

relationships to inform urban planning. Landsc Urban Plan 98: 13-25. The Building Center of Japan (2013) The Building Standard Law of Japan.

Watling J I, Nowakowski AJ, Donnelly MA, Orrock JL (2011) Meta-analysis reveals the importance of matrix composition for animals in fragmented habitat. Glob Ecol Biogeogr 20: 209-217. Williams ED (1979) Studies on the depth distribution and on the germination and growth of Equisetum arvense L. (field horsetail) from tubers. Weed Res 19: 25-32. macroscale biodiversity through land-use change in a human-dominated world. Oikos 120: 427451 


\section{Figure legends}

434 Fig. 1. The amount of solar radiation across Sapporo. Square structures and areas with 435 low solar radiation indicate buildings and building gaps, respectively. Inserts contain 436 detailed photographs of the study sites

437 Fig. 2. Study area, including the locations of the 85 study sites, and a representative 438 photograph of a survey site.

439 Fig. 3. Representative habitats in Sapporo urban area for four main fern species.

440 (a) Equisetum arvense L., (b) Matteuccia struthiopteris (L.) Tod., (c) Dryopteris 441 crassirhizoma Nakai, (d) Athyrium yokoscense (Franch. et Sav.) H.Christ.

442 Fig.4. Relationships between the occurrence probabilities of five fern species and 443 ground cover type, habitat age, district type, solar radiation, and distance from 444 continuous forest. Predicted lines were derived from generalized linear mixed models 445 (GLMMs; see details in the main text). Solid and broken lines indicate significant $(P<$ 446 0.05) and non-significant effects, respectively, of each explanatory variable. In 447 producing these figures, we used the appropriate mean values for plot area and the 448 environmental variables, and zero for the random effects. 
451 Table 1. Definitions of district types used in this study.

452 Table 2. Coefficients and standard errors (SEs) of five environmental variables in the 453 generalized linear mixed models (GLMMs) for five fern species. Standard deviations of 454 each model are also shown.

455

456 Supporting information

457 Appendix 1. A list of 29 fern species observed in this study.

458 Appendix 2. Pearson's correlations for environmental variables (ground cover types,

459 habitat age, district types, amount of solar radiation, and distance from continuous 460 forest). 


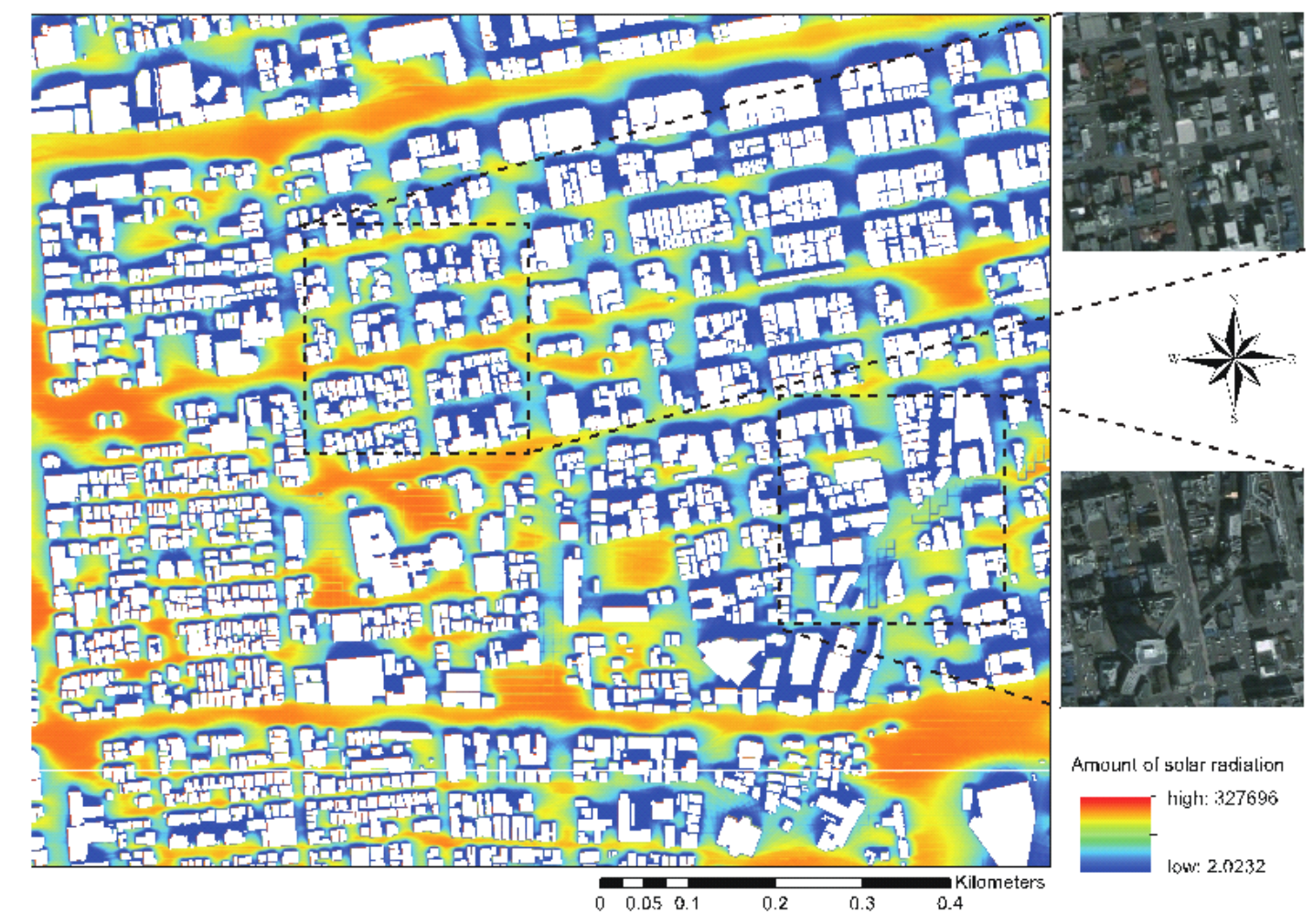

463 Fig. 1. The amount of solar radiation across Sapporo. 


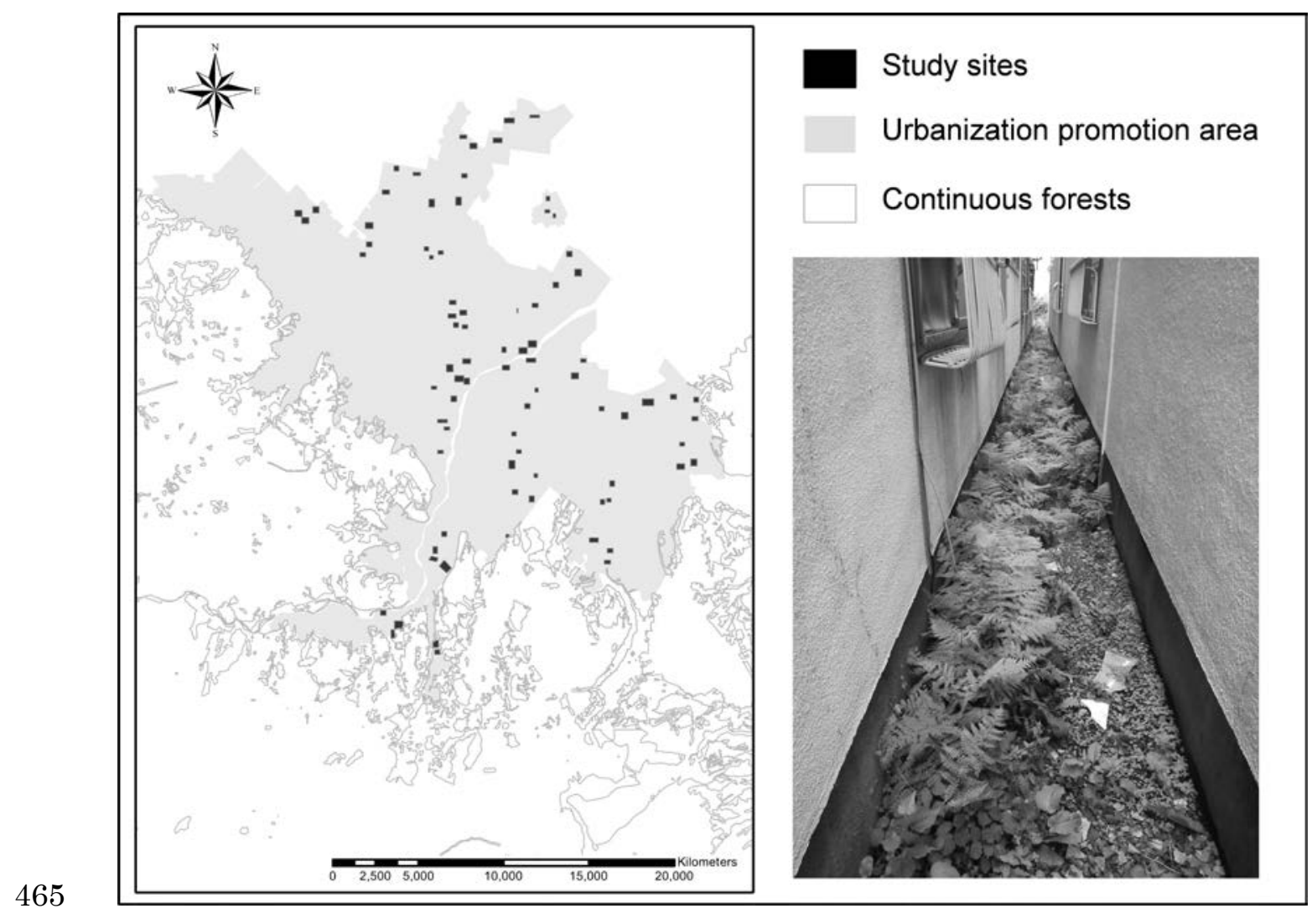

466 Fig. 2. Study area, including the locations of the 85 study sites, and a representative 467 photograph of a survey site. 

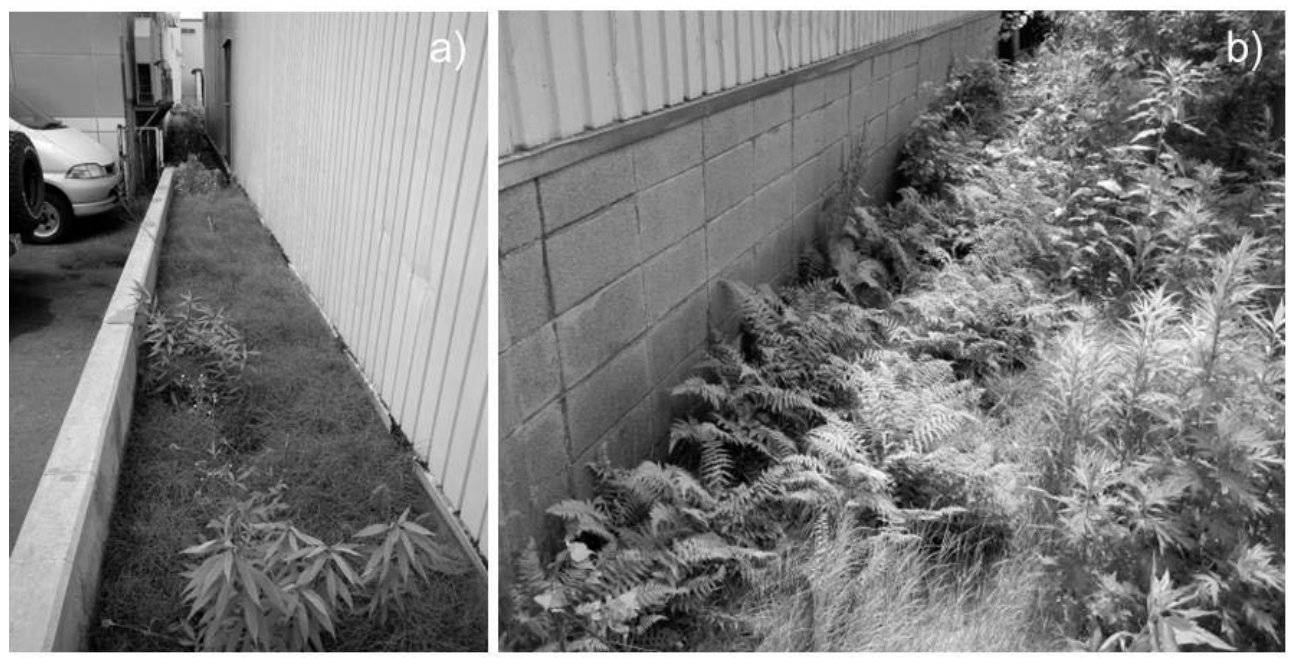

469
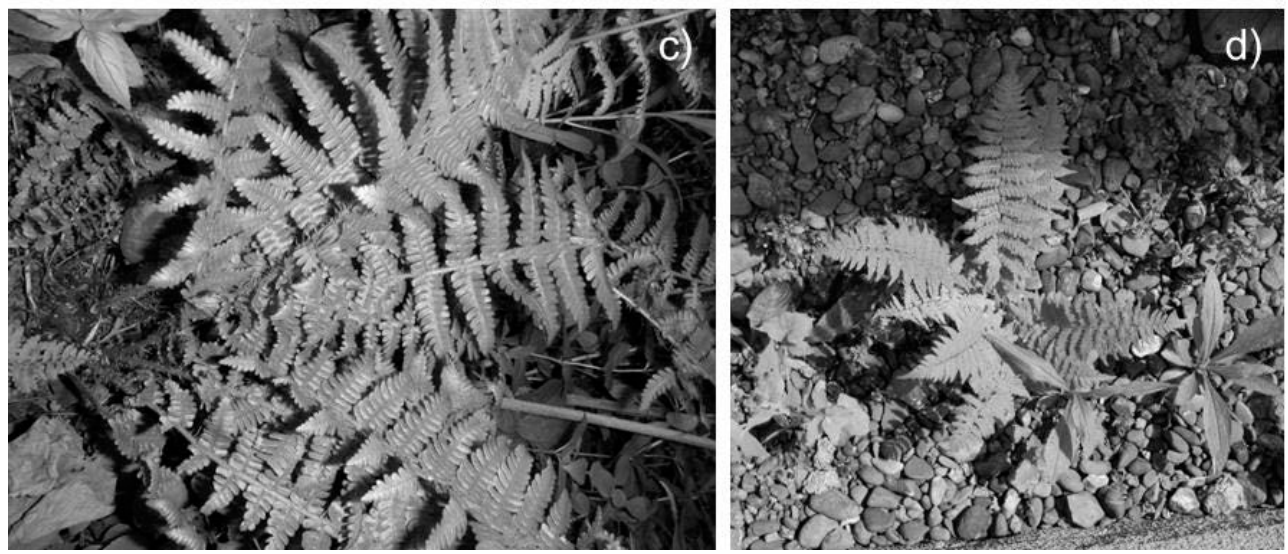

Fig. 3. Representative habitats in Sapporo urban area for four main fern species.

(a) Equisetum arvense L., (b) Matteuccia struthiopteris (L.) Tod., (c) Dryopteris 

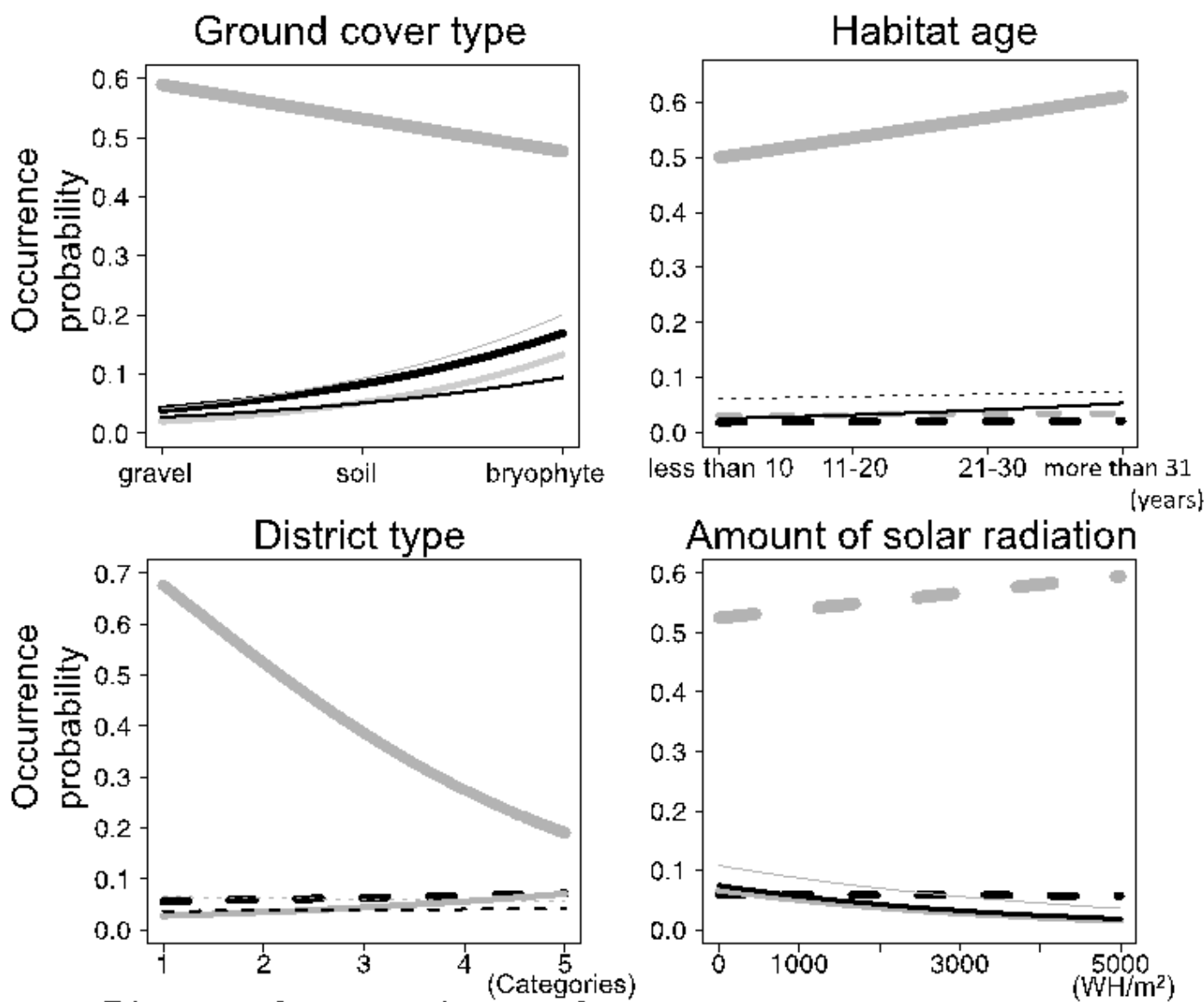

Amount of solar radiation

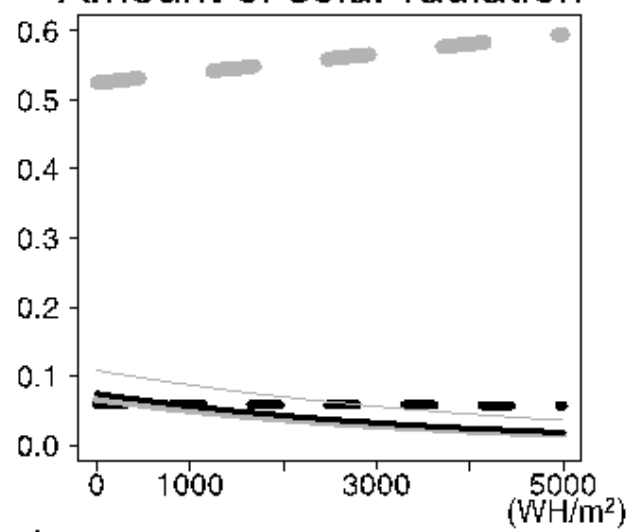

Distance from continuous forest
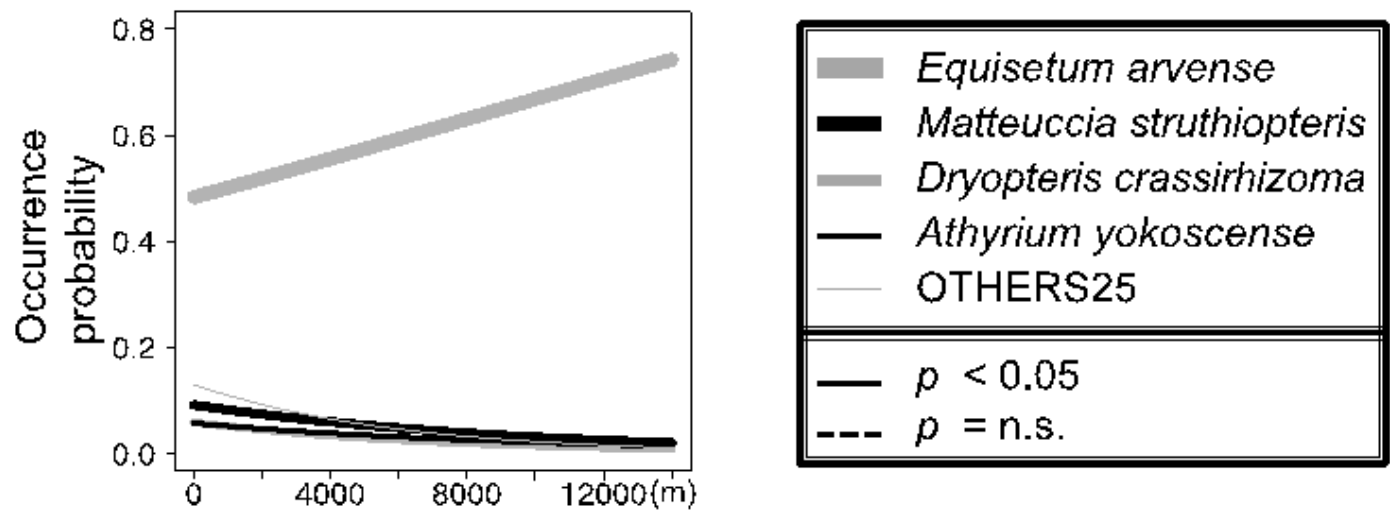

Fig. 4 Relationships between the occurrence probabilities of five fern species and

476 ground cover type, habitat age, district type, solar radiation, and distance from continuous forest. 
479 Table 1. Definitions of district types used in this study.

\begin{tabular}{|c|c|c|c|c|}
\hline Categories & $\begin{array}{l}\text { Building to } \\
\text { land ratio }\end{array}$ & $\begin{array}{l}\text { Floor area } \\
\text { ratio }^{2}\end{array}$ & District type & \# plots \\
\hline 1 & 40 & 80 & $\begin{array}{l}\text { category } 1 \text { low rise-rise } \\
\text { exclusive residential districts, } \\
\text { category } 2 \text { low-rise exclusive } \\
\text { residential districts }\end{array}$ & 1363 \\
\hline 2 & 50 & 80 & $\begin{array}{l}\text { category } 1 \text { medium-to-high-rise } \\
\text { exclusive residential districts, } \\
\text { category } 2 \text { medium-to-high-rise } \\
\text { exclusive residential districts, } \\
\text { category } 1 \text { residential districts, } \\
\text { category } 2 \text { residential districts, } \\
\text { quasi-residential districts }\end{array}$ & 574 \\
\hline 3 & 60 & 200 & $\begin{array}{l}\text { quasi-industrial districts, } \\
\text { industrial districts }\end{array}$ & 194 \\
\hline 4 & 80 & $200 \sim 300$ & $\begin{array}{l}\text { neighborhood commercial } \\
\text { districts }\end{array}$ & 112 \\
\hline 5 & 80 & $400 \sim 800$ & commercial districts & 130 \\
\hline
\end{tabular}

480 From the Building Standard Law of Japan

$481{ }^{1}$ Proportion of the area covered by the buildings

$482 \quad{ }^{2}$ The ratio of the area to total building floor

483 
Table 2. Coefficients and standard errors (SEs) of five environmental variables in the generalized linear mixed models (GLMMs) for five fern species.

\begin{tabular}{|c|c|c|c|c|c|c|}
\hline \multicolumn{7}{|c|}{$\begin{array}{l}\text { a) Parameter estimates of regression } \\
\text { analysis }\end{array}$} \\
\hline Fixed effects: & & E. arvense & M. struthiopteris & $\begin{array}{r}D . \\
\text { crassirhizoma }\end{array}$ & A. yokoscense & OTHERS25 \\
\hline \multirow[t]{3}{*}{ Intercept } & Estimate & -1.356 & -5.239 & -5.68 & -5.4 & -4.328 \\
\hline & SE & 0.2011 & 0.4273 & 0.05005 & 0.5183 & 0.3878 \\
\hline & & $p<0.001$ & $p<0.001$ & $p<0.001$ & $p<0.001$ & $p<0.001$ \\
\hline \multirow[t]{3}{*}{ Ground cover } & Estimate & -0.1585 & 0.7574 & 0.9801 & 0.6396 & 0.8312 \\
\hline & $\mathrm{SE}$ & 0.04822 & 0.09621 & 0.1109 & 0.1156 & 0.08834 \\
\hline & & $p<0.01$ & $p<0.001$ & $p<0.001$ & $p<0.001$ & $p<0.001$ \\
\hline \multirow[t]{3}{*}{ Habitat age } & Estimate & 0.1025 & 0.03681 & 0.05118 & 0.2573 & 0.06525 \\
\hline & $\mathrm{SE}$ & 0.04001 & 0.09629 & 0.1124 & 0.1165 & 0.08854 \\
\hline & & $p<0.05$ & & & $p<0.05$ & \\
\hline \multirow[t]{3}{*}{ District type } & Estimate & -0.4192 & 0.06566 & 0.2432 & 0.03334 & -0.04371 \\
\hline & SE & 0.05939 & 0.09281 & 0.1039 & 0.1066 & 0.08922 \\
\hline & & $p<0.001$ & & $p<0.05$ & & \\
\hline \multirow{2}{*}{$\begin{array}{l}\text { Amount of } \\
\text { solar radiation }\end{array}$} & Estimate & 0.00003898 & -0.00001032 & -0.0002966 & -0.0002854 & -0.000228 \\
\hline & SE & 0.00003111 & 0.00007241 & $\begin{array}{r}0.00009193 \\
p<0.01\end{array}$ & $\begin{array}{r}0.00009522 \\
p<0.01\end{array}$ & $\begin{array}{r}0.00006876 \\
p<0.001\end{array}$ \\
\hline \multirow{3}{*}{$\begin{array}{l}\text { Distance from } \\
\text { continuous forest }\end{array}$} & Estimate & 0.00005139 & -0.0001108 & -0.0001432 & -0.000101 & -0.0001802 \\
\hline & SE & 0.00001804 & 0.00003636 & 0.00004803 & 0.00004349 & 0.00003718 \\
\hline & & $p<0.01$ & $p<0.01$ & $p<0.01$ & $p<0.05$ & $p<0.001$ \\
\hline $\begin{array}{l}\text { Random effects: } \\
\text { site }=85\end{array}$ & SD & 0.4774 & 0.5792 & 0.6716 & 0.6396 & 0.5389 \\
\hline
\end{tabular}




\begin{tabular}{lrrrr}
\hline b) Ranges of environmental & Min & Max & Mean & SD \\
variables & 1 & 27.04 & 4.745 & 2.746 \\
Area & 1 & 3 & 1.521 & 0.727 \\
Ground cover & 1 & 4 & 2.641 & 0.866 \\
Habitat age & 1 & 5 & 1.766 & 1.133 \\
$\begin{array}{l}\text { District type } \\
\text { Amount of }\end{array}$ & 4.151 & 5830 & 2459 & 1160.624 \\
solar radiation & & & & \\
$\begin{array}{l}\text { Distance from } \\
\text { continuous forest }\end{array}$ & 16.6 & 13780 & 4191 & 3285.057 \\
\hline
\end{tabular}


Appendix 1. A list of 29 fern species observed in this study.

\begin{tabular}{|c|c|c|c|c|}
\hline No. & Family & Species & \# plots $^{1}$ & Proportion $^{2}$ \\
\hline 1 & Equisetaceae & Equisetum arvense $\mathrm{L}$. & 1292 & 54.38 \\
\hline 2 & Athyriaceae & Matteuccia struthiopteris (L.) Tod. & 190 & 8.00 \\
\hline 3 & Dryopteridaceae & Dryopteris crassirhizoma Nakai & 143 & 6.12 \\
\hline 4 & Woodsiaceae & Athyrium yokoscense (Franch. et Sav.) H.Christ & 133 & 5.57 \\
\hline 5 & Woodsiaceae & Onoclea orientalis (Hook.) Hook. & 58 & 2.43 \\
\hline 6 & Woodsiaceae & Athyrium melanolepis (Franch. et Sav.) H.Christ & 56 & 2.39 \\
\hline 7 & Equisetaceae & Equisetum palustre L. & 33 & 1.38 \\
\hline 8 & Thelypteridaceae & Thelypteris palustris (Salisb.) Schott & 28 & 1.17 \\
\hline 9 & Woodsiaceae & Deparia conilii (Franch. et Sav.) M.Kato & 27 & 1.13 \\
\hline 10 & Woodsiaceae & Athyrium vidalii (Franch. et Sav.) Nakai & 18 & 0.75 \\
\hline 11 & Woodsiaceae & Athyrium deltoidofrons Makino & 17 & 0.71 \\
\hline 12 & Aspleniaceae & Asplenium incisum Thunb. & 11 & 0.50 \\
\hline 13 & Dennstaedtiaceae & Pteridium aquilinum var. latiusculum & 11 & 0.46 \\
\hline 14 & Thelypteridaceae & Thelypteris phegopteris (L.) Sloss. ex Rydb. & 6 & 0.25 \\
\hline 15 & Woodsiaceae & Athyrium niponicum (Mett.) Hance & 6 & 0.25 \\
\hline 16 & Dennstaedtiaceae & Dennstaedtia wilfordii (T.Moore) H.Christ ex C.Chr. & 4 & 0.17 \\
\hline 17 & Dryopteridaceae & Polystichum polyblepharon (Roem. ex Kunze) C.Presl & 4 & 0.17 \\
\hline 18 & Thelypteridaceae & Thelypteris nipponica (Franch. et Sav.) Ching & 3 & 0.13 \\
\hline 19 & Onocleaceae & Onoclea sensibilis L. var. interrupta Maxim. & 3 & 0.13 \\
\hline 20 & Thelypteridaceae & $\begin{array}{l}\text { Stegnogramma pozoi (Lag.) K.Iwats. subsp. mollissima } \\
\text { (Fisch. ex Kunze) K.Iwats. }\end{array}$ & 3 & 0.13 \\
\hline 21 & Woodsiaceae & Deparia pycnosora var. mucilagina & 2 & 0.08 \\
\hline 22 & Woodsiaceae & Woodsia manchuriensis Hook. & 2 & 0.08 \\
\hline 23 & Osmundaceae & Osmunda cinnamomea L. & 1 & 0.04 \\
\hline 24 & Woodsiaceae & Deparia pseudoconilii (Seriz.) Seriz. & 1 & 0.04 \\
\hline 25 & Blechnaceae & Blechnum niponicum (Kunze) Makino & 1 & 0.04 \\
\hline 26 & Dryopteridaceae & Arachniodes standishii (T.Moore) Ohwi & 1 & 0.04 \\
\hline
\end{tabular}




\begin{tabular}{lllrl}
\hline 27 & Woodsiaceae & Athyrium x multifidum Rosenst. & 1 & 0.04 \\
28 & Woodsiaceae & Cornopteris crenulatoserrulata (Makino) Nakai & 1 & 0.04 \\
29 & Lycopodiaceae & Lycopodium clavatum L. & 1 & 0.04 \\
\hline
\end{tabular}

${ }^{1}$ Number of plots at which each species occurred.

${ }^{2}$ Proportions of plots at which each species occurred among the 2,373 plots.

We used scientific names following "YList" http://bean.bio.chiba-u.jp/bgplants/index.html. 
Appendix 2. Pearson's correlations for environmental variables (ground cover types, habitat age, district types, amount of solar radiation, and distance from continuous forest).

\begin{tabular}{|c|c|c|c|c|}
\hline & Habitat age & Ground cover type & District type & Amount of solar radiation \\
\hline Ground cover type & 0.22 & & & \\
\hline District type & 0.09 & 0.06 & & \\
\hline $\begin{array}{l}\text { Amount of solar } \\
\text { radiation }\end{array}$ & -0.10 & -0.06 & -0.31 & \\
\hline $\begin{array}{c}\text { Distance from } \\
\text { continuous forest }\end{array}$ & -0.02 & -0.10 & 0.09 & -0.08 \\
\hline
\end{tabular}

